Article

\title{
Knowing and Doing: The Perception of Subsidy Policy and Farmland Transfer
}

\author{
Yali Zhang ${ }^{1,2}$, Yihan Wang ${ }^{3}$ and Yunli Bai ${ }^{1,2, * \mathbb{C}}$ \\ 1 Institute of Geographic Sciences and Natural Resources Research, Chinese Academy of Sciences, \\ Beijing 100101, China; zhangyali@igsnrr.ac.cn \\ 2 Center for Chinese Agricultural Policy, Chinese Academy of Sciences, Beijing 100101, China \\ 3 School of Economics and Management, China University of Geosciences, Beijing 100083, China; \\ 1007161014@cugb.edu.cn \\ * Correspondence: baiyl.11b@igsnrr.ac.cn; Tel.: +86-106-488-9835
}

Received: 19 February 2019; Accepted: 16 April 2019; Published: 23 April 2019

\begin{abstract}
Farmland transfer is conducive to the rational allocation of farmland resources and scaling of agricultural production in China. The Chinese government launched a pilot program to subsidize moderate-scale farmland management in 2016, yet the perception of the program and its effects are rarely empirically tested using micro-level data. Using data on 523 households extracted from a rural household survey, the Probit and Tobit model results determined a significant positive impact of the perception of moderate-scale subsidies on both farmland transfer behavior and farmland transfer area. If the household knows about the moderate-scale subsidy policy, then it is $19.2 \%$ more likely to have moderate-scale land endowment, and the household has 17.626 ha more inflow land than that who do not know the policy. The results show that only $5 \%$ of the households know the moderate-scale subsidy policy, thus hindering the process of farmland transfer. Additionally, high levels of educational attainment and non-agricultural income promote farmers' decisions to transfer farmland and to expand farmland areas for moderate-scale households. However, age, household size, the family dependency ratio, and non-agricultural labor are obstacles to farmland transfer. The findings imply that the government should adopt a more effective policy transmission mechanism to increase the proportion of knowing the subsidy policy for both small-scale and moderate-scale households.
\end{abstract}

Keywords: farmland transfer; perception of subsidy policy; small-scale households; moderate-scale households

\section{Introduction}

There is a long-standing international debate on small-sized versus large-sized farms given the inherent tension between food security and agricultural production efficiency [1,2]. According to the 2016 Global Food Policy Report, small- and medium-sized farms are the main contributors to global food security and nutrition [3]. More than half of the world's food supply is produced by small-sized farms, and the proportion is larger in low-income countries. Meanwhile, over $40 \%$ of global population depends on agriculture for their livelihood [1]. Therefore, many scholars reached a consensus that, when characterized as moderate-scale, smaller-sized farms will have a higher crop yield and play a significant role in food security for the low-income community [4-6].

In comparison with the large-sized farms in the United States (US) (178.87 ha in 2016), the average size of Chinese family farms in 2016 was 23.8 ha [7], and China's agriculture is primarily dominated by small farms [8]. China's farmland resources are relatively limited. With only $7 \%$ of the world's farmlands, China has difficulty in feeding $20 \%$ of the world's population [9]. According to the Chinese Ministry of Agriculture, the total farmland area in China was 134.96 million ha, but the average 
farmland area per household was less than 0.4 ha in 2016. The current situation gives rise to the growing contradiction between humans and farmland, and the resulting difficulties in agricultural operations [10]. Owing to the shortcomings of resources, labor force dynamics, agricultural machinery, and technology, the production cost of crops in China is obviously higher than that of other major crop-producing countries, such as the US, Canada, and Brazil [11]. Under these circumstances, China is one of the largest food importers in the world [12]. Meanwhile, urban expansion results in less available land for agriculture and greater pressure on food security in China [13]. Based on the current situation, the Chinese government formulated a national grain self-sufficiency target of 95\% [14]. Compared with the current small-sized farms, moderate-scale farms which are more conducive to agricultural production at scale can alleviate China's food security problems to some extent [15]. However, there are still many challenges to realizing moderate-scale production across the whole country. Several developing countries are in similar situations, such as India, Indonesia, and other Asian countries [16-18].

The Chinese government took measures to guide the process of farmland transfer to achieve moderate-scale production [10]. Several scholars studied a great number of the determinants of farmland transfer, including resource endowment, household characteristics, individual characteristics, and policy and systems (Table 1). Similar to China, Organization for Economic Co-operation and Development (OECD) countries like France and Japan are characterized by small-farm agriculture. Both countries implemented subsidy policies to protect farmers with farmland outflow. In contrast, the Chinese government issued subsidy policies to motivate moderate-scale production of farmers with farmland inflow in 2015 [19]. In addition, the Chinese government also implemented a series of policies to promote farmland transfer, including improving the registration system of farmland contractual management rights, strengthening control of land use, encouraging innovation in forms of farmland transfer, standardizing the behavior of farmland transfer, and so on [20,21]. With great effort from the Chinese government, the total area of transferred farmland reached 31.40 million ha by the end of 2016, over one-third of the total area of contracted farmland (farmland area allocated to each rural household by collective economic organizations under the contract responsibility system issued by the Chinese government in 1991) [22]. Farmland transfer is of great benefit to rural economic development, which is to be further promoted in China.

Table 1. Determinants of farmland transfer behavior in previous studies.

\begin{tabular}{|c|c|c|c|}
\hline & Determinants & Mechanism & Reference \\
\hline \multirow{9}{*}{$\begin{array}{c}\text { Resource } \\
\text { endowment }\end{array}$} & Topography & Flat farmland is easier to be transferred. & {$[23,24]$} \\
\hline & Soil quality & $\begin{array}{l}\text { High-quality farmland is easier to be } \\
\text { transferred. }\end{array}$ & [25] \\
\hline & Farmland fragmentation & $\begin{array}{l}\text { Fragmented farmland is more difficult to be } \\
\text { transferred. }\end{array}$ & {$[23,26]$} \\
\hline & $\begin{array}{l}\text { Regional economic } \\
\text { development }\end{array}$ & $\begin{array}{l}\text { High level of regional economic development } \\
\text { promotes farmland transfer. }\end{array}$ & [27] \\
\hline & Production mode & $\begin{array}{l}\text { Optimized production mode is beneficial to } \\
\text { farmland transfer. }\end{array}$ & [25] \\
\hline & Irrigation conditions & $\begin{array}{l}\text { Improved irrigation conditions are conducive } \\
\text { to farmland transfer. }\end{array}$ & [28] \\
\hline & $\begin{array}{l}\text { Distance from farmland } \\
\text { to product markets }\end{array}$ & $\begin{array}{l}\text { The distance indirectly affects the demand of } \\
\text { farmland in the land market. }\end{array}$ & {$[27,29]$} \\
\hline & $\begin{array}{l}\text { Area of farmland per } \\
\text { capita }\end{array}$ & $\begin{array}{l}\text { More area of farmland per capita promotes } \\
\text { farmland transfer. }\end{array}$ & {$[23,24,29]$} \\
\hline & $\begin{array}{l}\text { Agricultural income per } \\
\text { unit area }\end{array}$ & $\begin{array}{l}\text { More agricultural income per unit area } \\
\text { obstructs farmland transfer. }\end{array}$ & [27] \\
\hline & $\begin{array}{l}\text { Proportion of agriculture } \\
\text { labor }\end{array}$ & $\begin{array}{l}\text { Sufficient agricultural labor hinders farmland } \\
\text { transfer. }\end{array}$ & {$[24,27]$} \\
\hline $\begin{array}{l}\text { Household } \\
\text { characteristics }\end{array}$ & Family assets & $\begin{array}{l}\text { Households with more family assets are } \\
\text { reluctant to transfer farmland. }\end{array}$ & [25] \\
\hline
\end{tabular}


Table 1. Cont.

\begin{tabular}{|c|c|c|c|}
\hline & Determinants & Mechanism & Reference \\
\hline & Household size & $\begin{array}{l}\text { Household size has a negative impact on } \\
\text { farmland transfer. }\end{array}$ & {$[30]$} \\
\hline & $\begin{array}{l}\text { Family demographic } \\
\text { structure }\end{array}$ & $\begin{array}{l}\text { Households with more children and labor are } \\
\text { more willing to transfer farmland. }\end{array}$ & {$[23,31-33]$} \\
\hline & Family Engel coefficient & $\begin{array}{l}\text { Low family Engel coefficient fosters farmland } \\
\text { transfer. }\end{array}$ & {$[27,29]$} \\
\hline \multirow{5}{*}{$\begin{array}{c}\text { Individual } \\
\text { characteristics }\end{array}$} & $\begin{array}{l}\text { Non-agriculture } \\
\text { employment }\end{array}$ & $\begin{array}{l}\text { Opportunities of non-agricultural } \\
\text { employment promote farmland transfer. }\end{array}$ & {$[23,34]$} \\
\hline & Non-agriculture income & $\begin{array}{l}\text { Non-agricultural income positively affects } \\
\text { farmland transfer. }\end{array}$ & [35-37] \\
\hline & Educational attainment & $\begin{array}{l}\text { High educational attainment accelerates } \\
\text { farmland transfer. }\end{array}$ & {$[24,29]$} \\
\hline & Health level & $\begin{array}{l}\text { Improved nutritional status hinders farmland } \\
\text { transfer. }\end{array}$ & [24] \\
\hline & Age & $\begin{array}{l}\text { Old farmers are more reluctant to transfer } \\
\text { land. }\end{array}$ & {$[24,29]$} \\
\hline \multirow{3}{*}{$\begin{array}{l}\text { Policy and } \\
\text { systems }\end{array}$} & Policy reform & $\begin{array}{l}\text { Public policy reform fosters farmland } \\
\text { transfer. }\end{array}$ & {$[38]$} \\
\hline & Land property rights & $\begin{array}{l}\text { Clear property rights have a positive } \\
\text { influence on farmland transfer. }\end{array}$ & [39-41] \\
\hline & Land market & $\begin{array}{l}\text { Incomplete land market resists farmland } \\
\text { transfer. }\end{array}$ & {$[33,38]$} \\
\hline
\end{tabular}

Although promoting agricultural development, farmland transfer has certain negative social and environmental consequences. Due to the special Hukou system in China (Chinese people are registered according to their urban or rural location of origin), it is difficult for individuals with rural Hukou status to find jobs in cities after farmland outflow without an effective governmental support system [42]. In addition, farmland transfer will drive agricultural intensification, which might have negative effects on biodiversity [43] and climatic conditions [44]. In the process of farmland transfer, the Chinese government is gradually realizing these problems and adopting corresponding policy adjustments accordingly. For instance, the Hukou system was reformed to eliminate barriers between urban and rural areas and to protect the rights of the rural population.

The moderate-scale subsidy policy is one of the most important policies issued by the Chinese government to accelerate farmland transfer [19]. Since the reform of the country's subsidy policies in 2015, agricultural subsidies in China mainly include soil fertility subsidies and moderate-scale subsidies. The objective of moderate-scale subsidies is to promote farmland transfer and to change the present situation of small-farm agriculture in China. The contents of the moderate-scale subsidy policy comprise loan discounts, technology promotion, and service subsidies. The standard and amount of the subsidies vary among the different provinces. The Chinese government selected five provinces to carry out pilot reforms, including Anhui, Shandong, Hunan, Sichuan, and Zhejiang. As one of the pilot sites, Shandong Province is the main research area of our study. In order to fully mobilize the enthusiasm of farmers and promote moderate-scale production, the Shandong government subsidized $\$ 136$ per ha for households with farmland area between 3.33 ha and 13.33 ha [45]. Households with farmland area over 13.33 ha can obtain up to $\$ 1818$ from the government. According to the policy, we classify rural households in Shandong Province into small-scale households (with farmland area less than $3.33 \mathrm{ha}$ ) and moderate-scale households (with farmland area above $3.33 \mathrm{ha}$ ).

Several scholars carried out researches on the effect of farmers' perception on realization of the subsidy policies' objectives. Yi et al. [46] used panel data from the Research Center for Rural Economy (RCRE) and showed that $86 \%$ of the households receive subsidies and almost all of the households know their subsidy levels. Yi et al. concluded that farmers with a positive perception of the wired grain subsidies are willing to change their mode of agricultural production and management. In Hubei 
Province, Meng [47] found that farmers who have knowledge of the grain subsidy policy remain in rural areas, thereby affecting farmland transfer. Meng stated that the grain subsidy policy prevents farmers from leaving rural areas; therefore, more farmers are reluctant to conduct farmland outflow. Raut and Sitaula [48] examined the perception of fertilizer subsidy policy in Nepal based on data from a survey conducted in 1038 households. They stated that, although only a few farmers are aware of the changes in the subsidy policy, most of them are satisfied and would take action to expand production to make the policy effective.

In summary, among the studies of farmers' perceptions of subsidy policies, most studies concentrated on whether farmers' knowledge of policy affects their decision-making with respect to grain production. However, relatively few studies focused on the effect of the perception of subsidy policies on farmland transfer decisions. More specifically, few scholars focused on the new moderate-scale subsidy policy, and even fewer discussed the effects of knowing the moderate-scale subsidy policy on farmland transfer decision-making.

Hence, the overall goal of this paper is to study the effect of farmers' perceptions of the moderate-scale subsidy policy on farmland transfer. To realize this goal, we focus on two specific objectives: (a) evaluating the factors affecting the total rural households' decisions on farmland transfer, and (b) discussing the determinants of the inflow area and total farmland area holdings by moderate-scale households.

\section{Approach and Methods}

\subsection{Sampling}

The data used in this study were collected from a representative survey conducted in the main grain-producing areas located in Shandong Province in China in 2017 (data for 2016). For the sake of the randomness of samples, rural areas in Jinan, Weifang, and Dezhou municipalities were chosen as the main research objectives according to their high, medium, and low levels of socioeconomic development, respectively. According to the Shandong Statistical Yearbook (2018), the average proportion of the rural population for the three municipalities was 38\% in 2017, compared to the national average of $41 \%$. The disposable income per capita of rural residents in each of the three municipalities was $\$ 2514$, $\$ 2642$, and $\$ 2029$, respectively. In that year, the disposable income per capita of the whole country was \$2035. Furthermore, the farmland area per capita in the three municipalities was 0.084 ha, while that of the whole country was 0.091 ha [49]. Thus, the rural area of three municipalities can be considered as approximately representative of the overall level of rural development in China.

The second step of the sample selection involved choosing administrative villages and households. Within each city, seven administrative villages were selected based on their agricultural development levels (Figure 1). Based on family income level, 20 households were chosen in each village. In addition, to guarantee the integrity of the samples, a set number of moderate-scale households were investigated. In total, 423 small-scale households (163 in Jinan, 210 in Weifang, and 150 in Dezhou) and 100 moderate-scale households (62 in Jinan, 25 in Weifang, and 13 in Dezhou) were interviewed in the field survey.

As one of the largest agricultural provinces in China, Shandong Province is a pilot area for moderate-scale subsidies in China. Located in the plains of northern China, Shandong Province has farmland area of 7.62 million ha, accounting for $5.65 \%$ of the total farmland area in China [49]. According to the Shandong Statistical Yearbook (2018), the total agricultural gross domestic product (GDP) was $\$ 67$ billion, and the agricultural output was 53 million tons in 2017. The rural population was 15,965 spread among 4,882 households at the end of 2017. Agricultural resources, including farmland resources and labor resources, are abundant in Shandong Province; however, the resources are not allocated rationally [50]. Under the moderate-scale subsidy policy and related social security system, the farmland transfer transactions are increasing steadily in Shandong Province. The area 
of transferred farmland in Shandong Province accounted for 32.3\% of the total area of contracted farmland by 2017 [51].

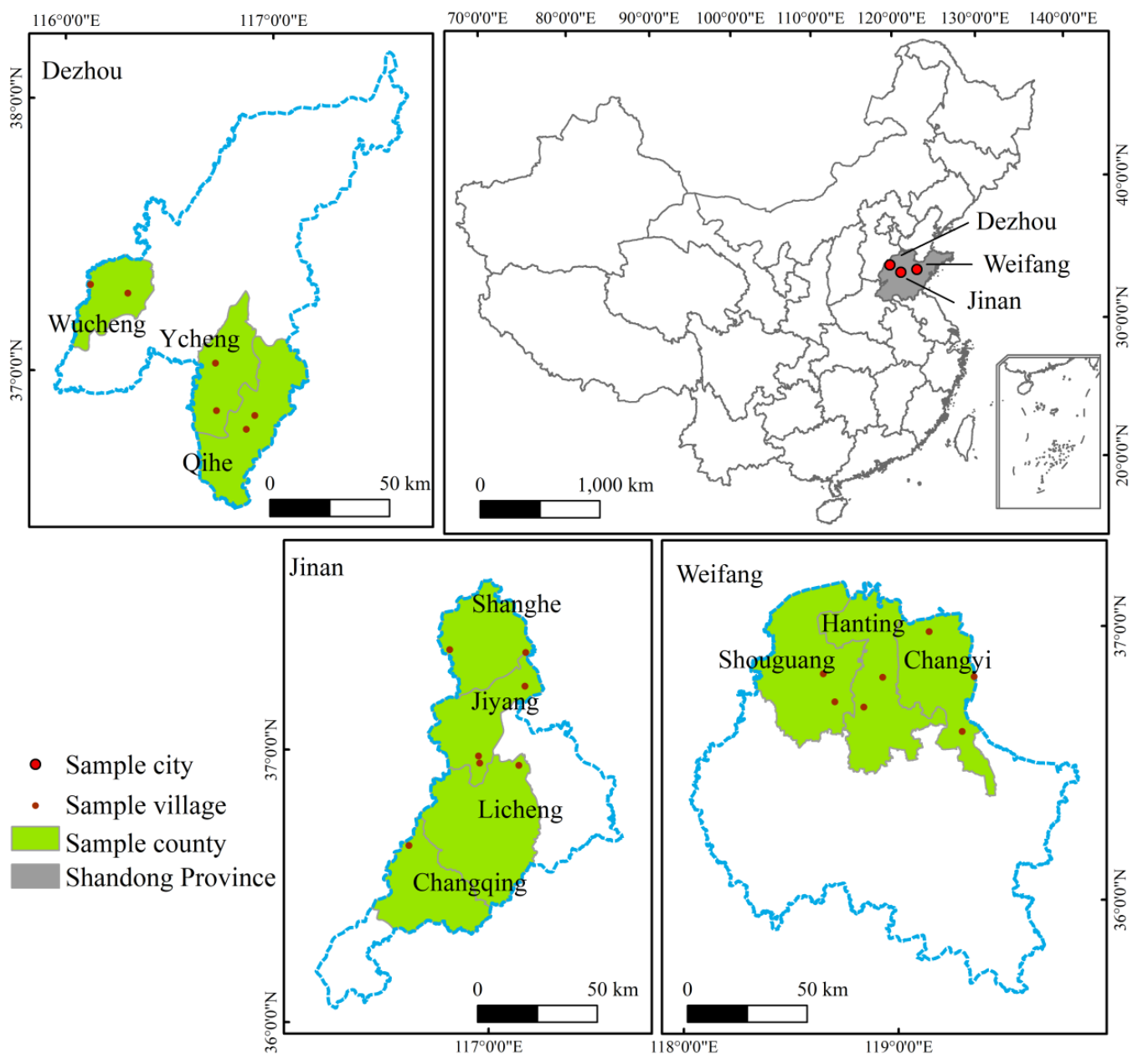

Figure 1. Map of sample village distribution.

\subsection{Data Collection}

This survey collected data from a field study to examine the determinants for farmland transfer. The data mainly consisted of farmland situation, farmer characteristics, household characteristics, and non-agricultural income levels. Firstly, the farmland situation at the household level was investigated. The questionnaires contained the following information: (1) the area of the contracted farmland; (2) the cumulative reduction of farmland area due to a change of use, damage, or other reasons; (3) the area of farmland inflow from renting or staking in; and (4) the area of farmland outflow from subcontracting, transferring with compensation, or leasing. These data were collected to reflect farmland under management in each household by the end of 2016. Secondly, each farmer's characteristics, including age, educational attainment, and knowledge of the moderate-scale subsidy policy, were investigated in the questionnaires. Thirdly, household characteristics, including household sizes, average ages, employment situations, and incomes, were investigated. The ages of all family members were used to calculate the average age of the household. The family dependency ratio was calculated as the non-labor population divided by the labor population. Furthermore, the proportions of farmers' non-agricultural labor and income were also calculated (The questionnaire about farmers' policy perception is shown in Table S1 of Supplementary Materials).

The effect of each factor on the farmland transfer is further discussed in a later section of this paper. On the basis of the investigated data, we analyzed the main reasons driving farmland inflow 
in both small-scale and moderate-scale households. In addition, we explored the factors affecting farmland inflow area and total farmland area in moderate-scale households.

\subsection{Empirical Approach}

We conducted two types of analysis, a Probit regression and a Tobit regression, to explore the relationship between the variable of knowing the policy and farmland transfer, respectively. The Probit model was used to analyze different determinants of the decision to become a moderate-scale household. The Tobit model was further applied in the analysis of the determinants of the inflow area and the total area of moderate-scale households.

\subsubsection{Probit Regression}

Probit model is commonly used to solve the problem of discrete dependent variables in agricultural economy. The model is formulated as follows:

$$
\begin{aligned}
& \mathrm{P}(y=1 \mid x)=\alpha+\beta \mathrm{K}_{i}+\gamma \mathrm{F}_{i}+\theta \mathrm{H}_{i}+\mathrm{u}_{i}, \\
& \mathrm{P}(y=0 \mid x)=\alpha+\beta \mathrm{K}_{i}+\gamma \mathrm{F}_{i}+\theta \mathrm{H}_{i}+\mathrm{u}_{i},
\end{aligned}
$$

where $\mathrm{P}$ refers to the probability of being a moderate-scale household, $\mathrm{K}_{i}$ represents the variable of knowing the policy $(1=$ yes, $0=\mathrm{no})$, and $\mathrm{F}_{i}$ represents the vector of household characteristics. These characteristics include household size, dependency ratio, average age of family members, proportion of non-agricultural labor, and non-agricultural income in 2016. Previous studies confirmed the influence of these variables on farmland transfer. Household size and family farm scale have a negative correlation, which indicates that, with more family members, a rural household is more reluctant to conduct farmland inflow [31]. Moreover, a high family dependency ratio will inhibit land inflow decision-making [32]. In addition, age blocks the process of farmland transfer, owing to the conservative mindset of older farmers [24]. Lastly, higher non-agricultural employment and income play a negative role in the inflow of farmland [26,27]. $\mathrm{H}_{i}$ represents the vector of characteristics of household head, such as age, square of age, and educational attainment. The positive effect of educational attainment on farmland decisions was identified by $\mathrm{Xu}$ et al. [36]. The characteristics of the variables are shown in Table 2 . The error term is represented by $\mathbf{u}_{i}$.

\subsubsection{Tobit Regression}

In addition, a Tobit regression can deal with truncated data; thus, we adopted this approach as a regression model for analyzing the impact of knowing the subsidy policy on the farmland area. The Tobit model is formulated as follows:

$$
\begin{gathered}
Y_{i}^{*}=\alpha+\beta \mathrm{K}_{i}+\gamma \mathrm{F}_{i}+\theta \mathrm{H}_{i}+\mathrm{u}_{i}, \\
Y_{i}^{*}=Y_{i} \text { if } Y_{i}^{*}>0, \\
Y_{i}^{*}=Y_{i} \text { if } Y_{i}^{*} \leq 0,
\end{gathered}
$$

where $Y_{i}$ represents inflow and total farmland area of moderate-scale households. Control variables in the Tobit regression are the same as in the Probit regression.

\section{Results}

\subsection{Descriptive Statistics of Farmland Transfer Decisions and Their Determinants}

As shown in Table 2, 423 small-scale households and 100 moderate-scale households were investigated. Only $5 \%$ of the investigated farmers knew the moderate-scale subsidy policy, implying that a large number of farmers were absolutely ignorant of the policy. The average household size 
and family dependency ratio in the samples were 4 and 0.85 , respectively (Table 2 ). With respect to farmers' characteristics, farmers received poor education, and most farmers only reached primary or junior high school levels. Low educational attainment is bound to have a negative influence on their decision-making regarding farmland transfer to some extent. The farmers' average age was 54 , which indicates that some of the farmers might have been suffering from mid-life crises and shouldering heavy burdens [45]. Regarding the level of non-agricultural employment, the survey found that the average proportion of the non-agricultural population in households was $30 \%$ and the average non-agricultural income was approximately $\$ 7625.5$.

Table 2. Characteristics of rural households.

\begin{tabular}{|c|c|c|c|c|c|}
\hline Variables & Define/Measurement & $\begin{array}{c}\text { (1) } \\
\text { Mean }\end{array}$ & $\begin{array}{l}(2) \\
\text { Var }\end{array}$ & $\begin{array}{c}(3) \\
\text { Min }\end{array}$ & $\begin{array}{l}\text { (4) } \\
\text { Max }\end{array}$ \\
\hline (1) Moderate-scale households & $(1=$ yes $; 0=$ no $)$ & 0.20 & 0.40 & 0 & 1 \\
\hline (2) Knowing the policy & $(1=$ yes $; 0=$ no $)$ & 0.05 & 0.21 & 0 & 1 \\
\hline (3) Household size & Number of people & 3.98 & 1.73 & 1 & 10 \\
\hline (4) Family dependency ratio & $\%$ & 0.85 & 0.92 & 0 & 3 \\
\hline (5) Average age of household members & Years & 43.84 & 13.59 & 15.75 & 82.5 \\
\hline (6) Non-agricultural labor proportion & $\%$ & 30.25 & 40.73 & 0 & 100 \\
\hline (7) Non-agricultural income & Dollars & 7625.5 & 3861.9 & 0 & 534,303 \\
\hline (8) Age of household head & Years & 54.84 & 11.19 & 23 & 83 \\
\hline (9) Square of age of household head & - & 3133 & 1233 & 529 & 6889 \\
\hline (10) Educational attainment & $\begin{array}{l}(1=\text { illiterate; } 2= \\
\text { primary school; } 3= \\
\text { junior high school; } 4= \\
\text { senior high school; } 5= \\
\text { college or above })\end{array}$ & 2.90 & 0.88 & 1 & 5 \\
\hline
\end{tabular}

There was farmland inflow in 119 small-scale households and 89 moderate-scale households (Figure 2a). Most moderate-scale households tended to have production at scale, and several small-scale households had the ability to expand their agricultural production to become moderate-scale households. A similar survey in Jiangxi Province showed that there were 775 households with farmland transfer behaviors, of which 323 rural households had inflow behaviors in 1396 valid questionnaires [52]. The number of households with farmland outflow was much lower than those with farmland inflow, which is consistent with research from $\mathrm{Xu}$ [53] and Yang and Chen [54]. This is mainly because these small-scale households acquire enough income from non-agricultural employment that it becomes an opportunity for them to separate themselves from agricultural production. In general, the proportion of households who had both farmland transfer inflow and outflow was 3.82\%.

Figure $2 \mathrm{~b}$ presents the area of farmland inflow and outflow. The area of farmland outflow was less than 4 ha in almost all the samples. Considering farmland inflow, 137 households with less than 4 ha inflow area were mainly small-scale households. These small-scale households had the ability to transform into moderate-scale households; however, the area of farmland inflow was still low. The area of farmland inflow in $9.56 \%$ of households varied from 4 ha to 12 ha, which is enough to make small-scale households become moderate-scale households. When realizing scale production, rural households can receive moderate-scale subsidies. In addition, a small number of farmers had farmland inflow areas exceeding $12 \mathrm{ha}$, which is beneficial for the reform of the agricultural management mode in the long run. 


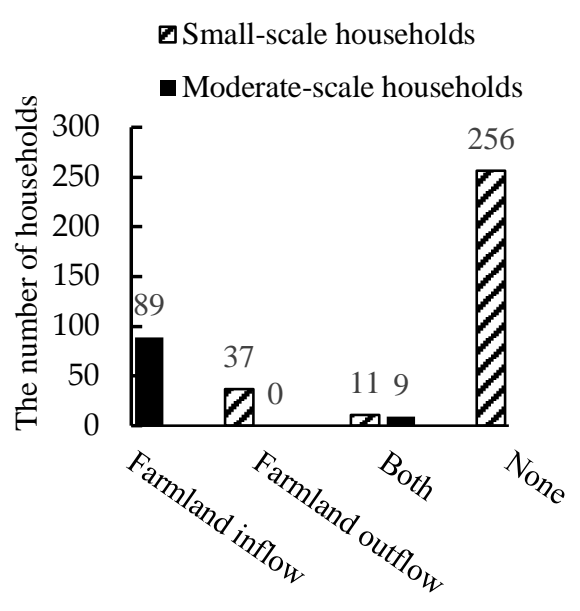

(a)

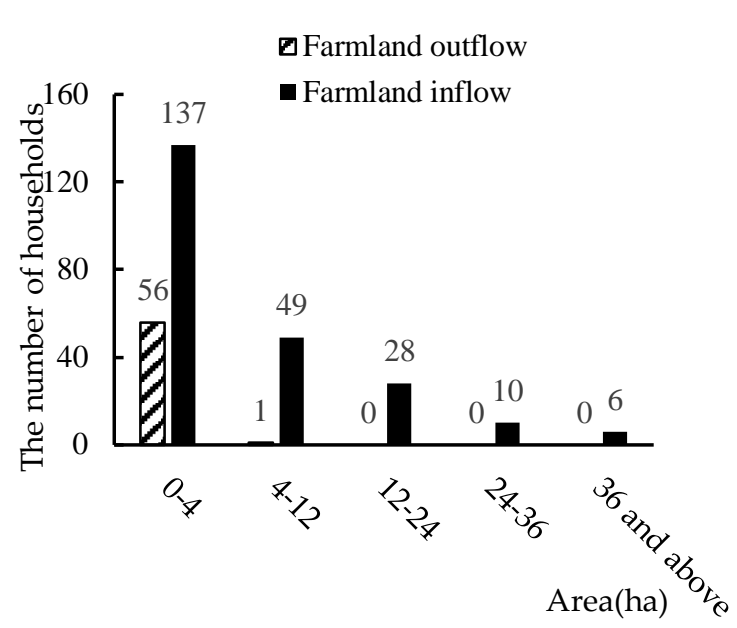

(b)

Figure 2. (a) Farmland transfer behaviors; (b) area of farmland transfer.

\subsection{Empirical Results}

To better understand the determinants of small-scale households and moderate-scale households' decisions regarding farmland transfer, the Probit model was utilized.

Most importantly, the results show that farmers prefer to transfer farmland when they know the moderate-scale subsidy policy (Table 3). If the farmers know about the moderate-scale subsidy policy, then they are $19.2 \%$ more likely to have moderate-scale land endowment. However, a large proportion of farmers do not have effective access to timely and advantageous subsidy policy information as a consequence of information delay and information asymmetry [55].

Table 3 also shows other important factors affecting farmland transfer. Non-agricultural employment significantly hinders farmland inflow. As more family members obtain jobs in non-agricultural industries, households' willingness to transfer farmland is greatly weakened. In addition, farmland transfer behavior is negatively related to household size, average age of household members, and family dependency ratio. All three variables represent the farmers' challenges in supporting the family [32]. In addition, the higher the farmers' level of educational attainment is, the more willing they are to transfer farmland. High educational attainment allows farmers to have sufficient ability to anticipate the market and understand the subsidy policy. At the same time, farmers with higher educational attainment will have a better understanding of both the local farmland environment and the regional development environment [36]. Moreover, rural labor participants with higher educational attainment are more likely to obtain a job after farmland outflow [56].

Although the results of each municipality are basically the same as that of the overall samples, there are significant differences among the three municipalities. Farmers in Dezhou and Jinan are willing to transfer farmland when they know the moderate-scale subsidy policy well, while there is no significance in Weifang. Similarly, educational attainment plays a significant role in motivating farmers to transfer farmland in Dezhou and Jinan, but its influence on farmers' behavior in Weifang is not significant. In addition, family dependency ratio has a significant adverse impact on farmland transfer in Weifang and Dezhou. Regarding the effect of age, the results showed that middle-aged people in Dezhou tend to be moderate-scale households, while young and old people in Jinan prefer to be moderate-scale households. The fact is due to that Jinan is closer to an urban area, and most middle-aged farmers in Jinan are more willing to seek non-agricultural employment. 
Table 3. Determinants of small-scale or moderate-scale land resource endowment

\begin{tabular}{|c|c|c|c|c|c|c|c|c|}
\hline \multirow[t]{2}{*}{ Variables } & \multicolumn{2}{|c|}{$\begin{array}{c}\text { Dependent Variable: Small-Scale } \\
\text { or Moderate-Scale Land Resource } \\
\text { Endowment }\end{array}$} & \multicolumn{2}{|c|}{ Dezhou } & \multicolumn{2}{|c|}{ Jinan } & \multicolumn{2}{|c|}{ Weifang } \\
\hline & Coefficients & Marginal Effects & Coefficients & Marginal Effects & Coefficients & Marginal Effects & Coefficients & Marginal Effects \\
\hline (1) Knowing the policy (1 = yes; & $1.220 * * *$ & $0.192 * * *$ & $1.940^{* *}$ & $0.162 * * *$ & $0.943 *$ & $0.203 *$ & 0.821 & 0.103 \\
\hline $0=$ no) & $(3.839)$ & (3.991) & $(2.439)$ & $(2.709)$ & $(1.649)$ & (1.697) & $(1.560)$ & $(1.618)$ \\
\hline (2) Household size (number & $-0.144^{* *}$ & $-0.028^{* * *}$ & -0.364 & -0.026 & -0.064 & -0.019 & 0.208 & 0.003 \\
\hline of people) & $(-2.116)$ & $(-2.844)$ & $(-1.597)$ & $(-1.635)$ & $(-0.702)$ & $(-0.702)$ & $(1.014)$ & $(1.025)$ \\
\hline \multirow{2}{*}{ (3) Family dependency ratio (\%) } & $-0.207^{*}$ & $-0.045^{* *}$ & -1.037 & -0.109 * & -0.091 & -0.002 & $-1.374^{* * *}$ & $-0.122 * *$ \\
\hline & $(-1.680)$ & $(-2.033)$ & $(-1.468)$ & $(-1.509)$ & $(-0.395)$ & $(-0.396)$ & $(-2.923)$ & $(-3.240)$ \\
\hline (4) Average age of household & $-0.022 * *$ & $-0.003 * *$ & -0.056 & -0.005 & -0.016 & -0.004 & -0.002 & -0.002 \\
\hline members (years) & $(-2.003)$ & $(-2.011)$ & $(-1.642)$ & $(-1.692)$ & $(-0.963)$ & $(-0.969)$ & $(-0.055)$ & $(-0.055)$ \\
\hline (5) Non-agricultural & $-0.016^{* * *}$ & $-0.007^{* * *}$ & -0.036 ** & $-0.001 * *$ & $-0.017^{* * *}$ & $-0.003 * * *$ & -0.010 ** & $-0.002 * * *$ \\
\hline proportion (\%) & $(-6.649)$ & $(-7.004)$ & $(-2.148)$ & $(-2.268)$ & $(-5.085)$ & $(-6.486)$ & $(-2.527)$ & $(-2.677)$ \\
\hline (6) Non-agricultural income in & 0.000 & 0.000 & 0.000 & 0.000 & 0.000 & 0.000 & 0.000 & 0.000 \\
\hline 2016 (dollars) & $(1.358)$ & $(1.301)$ & $(0.632)$ & $(0.634)$ & $(1.120)$ & $(1.127)$ & (1.002) & (1.011) \\
\hline \multirow{2}{*}{$\begin{array}{l}\text { (7) Age of household head } \\
\text { (years) }\end{array}$} & 0.035 & -0.010 & -0.290 & $-0.024 *$ & $0.221 * *$ & $0.047^{* * *}$ & 0.145 & 0.050 \\
\hline & $(0.567)$ & $(-1.035)$ & $(-1.631)$ & $(-1.722)$ & $(2.114)$ & $(2.174)$ & $(0.598)$ & $(0.599)$ \\
\hline (8) Square of age of household & -0.001 & 0.000 & $0.003 *$ & $0.000 *$ & $-0.003 * * *$ & $-0.001^{* * *}$ & -0.002 & -0.001 \\
\hline & $(-1.175)$ & $(0.328)$ & $(1.656)$ & $(1.742)$ & $(-2.624)$ & $(-2.743)$ & $(-0.905)$ & $(-0.910)$ \\
\hline \multirow{2}{*}{$\begin{array}{l}\text { (9) Educational attainment }(1= \\
\text { illiterate; } 2=\text { primary school; } 3= \\
\text { junior high school; } 4=\text { senior } \\
\text { high school; } 5=\text { college or above })\end{array}$} & $0.443^{* * *}$ & $0.048^{* * *}$ & $0.523 *$ & $0.048^{*}$ & $0.674^{* * *}$ & $0.132 * * *$ & 0.329 & 0.055 \\
\hline & $(4.030)$ & $(3.244)$ & $(1.703)$ & $(1.738)$ & $(3.893)$ & $(4.375)$ & $(1.273)$ & $(1.297)$ \\
\hline \multirow{2}{*}{ (10) Jinan $(1=$ yes; $0=$ no $)$} & $0.880^{* * *}$ & $0.129^{* * *}$ & - & - & - & - & - & - \\
\hline & $(4.141)$ & $(4.285)$ & - & - & - & - & - & - \\
\hline \multirow{2}{*}{ (11) Weifang $(1=$ yes; $0=$ no) } & 0.282 & 0.020 & - & - & - & - & - & - \\
\hline & $(1.204)$ & $(0.649)$ & - & - & - & - & - & - \\
\hline (12) Observations & 523 & 523 & 163 & 163 & 210 & 210 & 150 & 150 \\
\hline (13) $R^{2}$ & \multirow{2}{*}{\multicolumn{2}{|c|}{0.554}} & \multicolumn{2}{|c|}{0.425} & \multirow{2}{*}{\multicolumn{2}{|c|}{$\begin{array}{c}0.451 \\
114.820\end{array}$}} & \multirow{2}{*}{\multicolumn{2}{|c|}{$\begin{array}{c}0.360 \\
48.610\end{array}$}} \\
\hline (14) $\mathrm{Chi}^{2}$ & & & \multicolumn{2}{|c|}{38.540} & & & & \\
\hline
\end{tabular}

The $t$-statistics are shown in parentheses. ${ }^{* * *} p<0.01,{ }^{* *} p<0.05,{ }^{*} p<0.1$. The marginal effects of the coefficients are shown in column 2 . 
A total of 100 moderate-scale households were interviewed to analyze the present situation of farmland resources. According to the survey, the average farmland area in moderate-scale households is $16.33 \mathrm{ha}$, while the average inflow area is $15.80 \mathrm{ha}$. The inflow area occupies the majority of the total farmland area in moderate-scale households. Subsequently, the Tobit model was applied to study the relationship between the farmland inflow and total farmland area and their determinants.

The results revealed that knowing subsidy policy is the major factor affecting the moderate-scale households' decisions on the area of farmland inflow (Table 4). The household knowing the policy has 17.626 ha more inflow land than that which does not know the policy. The proportion of moderate-scale households knowing the content of the subsidy policy is $12 \%$, which is higher than that of small-scale households. Moderate-scale households pay more attention to the subsidy policy information pertaining to their circumstances. Economic compensation can enhance the enthusiasm of moderate-scale households and motivate them to make joint efforts toward farmland inflow and improving farmland quality [57]. In addition, farmers' perceptions of policy can serve as an impetus to the rational allocation of farmland resources to maximize output and profits [58].

As shown in Table 4, another main factor affecting farmland area in moderate-scale households is educational attainment. Farmers with higher educational attainment are more likely to change their traditional attitudes toward agricultural production and transfer farmland to achieve further accumulation of other production factors [27,59]. Moreover, farmers with higher levels of education can take advantage of local resource endowments to increase the content of science and technology in their agricultural practices [36]. Therefore, the ability to receive new technologies is vital for farmland transfer.

It is also necessary to observe the differences among the three municipalities. However, the sample size of moderate-scale households of each municipality is too small (see Figure S1 in Supplementary Materials). Hence, the result has no statistical significance.

Table 4. Determinants of farmland area of moderate-scale households.

\begin{tabular}{|c|c|c|}
\hline \multirow{2}{*}{ Variables } & \multicolumn{2}{|c|}{$\begin{array}{c}\text { Dependent Variable: Farmland Area of } \\
\text { Moderate-Scale Households }\end{array}$} \\
\hline & Inflow Area & Total Area \\
\hline (1) Knowing the policy $(1=$ yes; $0=$ no $)$ & $\begin{array}{l}264.392 * * * \\
(3.204)\end{array}$ & $\begin{array}{l}247.812^{* * *} \\
(3.183)\end{array}$ \\
\hline (2) Household size (number of people) & $\begin{array}{c}4.669 \\
(0.177)\end{array}$ & $\begin{array}{l}12.126 \\
(0.497)\end{array}$ \\
\hline (3) Family dependency ratio (\%) & $\begin{array}{c}1.062 \\
(0.023)\end{array}$ & $\begin{array}{l}1.283 \\
(0.030)\end{array}$ \\
\hline (4) Average age of household members (years) & $\begin{array}{c}1.518 \\
(0.425)\end{array}$ & $\begin{array}{l}1.407 \\
(0.420)\end{array}$ \\
\hline (5) Non-agricultural proportion (\%) & $\begin{array}{l}-0.468 \\
(-0.155)\end{array}$ & $\begin{array}{l}-0.219 \\
(-0.077)\end{array}$ \\
\hline (6) Non-agricultural income in 2016 (CNY) & $\begin{array}{l}-0.000 \\
(-0.659)\end{array}$ & $\begin{array}{l}-0.000 \\
(-0.662)\end{array}$ \\
\hline (7) Age of household head (years) & $\begin{array}{c}6.935 \\
(0.341)\end{array}$ & $\begin{array}{c}7.388 \\
(0.387)\end{array}$ \\
\hline (8) Square of age of household head & $\begin{array}{l}-0.076 \\
(-0.374)\end{array}$ & $\begin{array}{l}-0.070 \\
(-0.367)\end{array}$ \\
\hline $\begin{array}{l}\text { (9) Educational attainment }(1=\text { illiterate; } 2=\text { primary } \\
\text { school; } 3=\text { junior high school; } 4=\text { senior high school; } \\
5=\text { college or above })\end{array}$ & $\begin{array}{l}80.850 * * \\
(2.297)\end{array}$ & $\begin{array}{l}83.323^{* *} \\
(2.514)\end{array}$ \\
\hline (10) Jinan $(1=$ yes; $0=$ no $)$ & $\begin{array}{l}81.260 \\
(0.969)\end{array}$ & $\begin{array}{c}100.743 \\
(1.276)\end{array}$ \\
\hline (11) Weifang $(1=$ yes; $0=$ no $)$ & $\begin{array}{l}207.388^{* *} \\
\quad(2.245)\end{array}$ & $\begin{array}{l}218.995^{* *} \\
(2.513)\end{array}$ \\
\hline
\end{tabular}


Table 4. Cont.

\begin{tabular}{lcc}
\hline & Variables & \multicolumn{2}{c}{$\begin{array}{c}\text { Dependent Variable: Farmland Area of } \\
\text { Moderate-Scale Households }\end{array}$} \\
\cline { 2 - 3 } & Inflow Area & Total Area \\
\hline (12) Constant & -430.418 & -492.201 \\
$(13)$ Observations & $(-0.840)$ & $(-1.022)$ \\
$(14) R^{2}$ & 100 & 100 \\
(15) $\mathrm{Chi}^{2}$ & 0.015 & 0.015 \\
\hline
\end{tabular}

The $t$-statistics are shown in parentheses. ${ }^{* * *} p<0.01,{ }^{* *} p<0.05$.

\section{Discussion and Conclusions}

According to the Probit and Tobit model results, knowing the moderate-scale subsidy policy effectively accelerates farmland transfer behavior and, thus, promotes the moderate-scale production of small-sized farms. If the household knows about the moderate-scale subsidy policy, then it is $19.2 \%$ more likely to have moderate-scale land endowment. Due to the contribution of moderate-scale households' perception of the policy, the household has 17.626 ha more inflow land than that which does not know the policy, and farmland inflow areas dominate the total farmland area in moderate-scale households.

However, only $12 \%$ of moderate-scale households know the policy, and the reason for the ineffectiveness of the subsidy policy is the lack of active participation from the farmers [60]. The farmers' participation in farmland transfer is significantly affected by their understanding of related policies. In the meantime, the majority of farmers are insensitive to government subsidy policies due to their lack of legal consciousness and related knowledge [60]. Farmers' attitudes of indifference toward the policies contribute to the misalignment between the government's supply and the farmers' demands [61], which is harmful to long-term economic development in rural areas. Therefore, it is imperative to improve farmers' perception of the subsidy policy.

Several studies also revealed that knowing the policy affects the practice of farmland transfer, which is in accordance with our results. For example, Raut and Sitaula [48] found that, when 12\% of the farmers knew about a change in the fertilizer policy, $44 \%$ of those with that knowledge were willing to adjust their modes of agricultural production and operations. As Meng [47] observed, some farmers who received subsidies abandoned the opportunity to immigrate to cities. Therefore, rural labor remaining in rural areas is bound to influence farmland transfer decisions. In contrast, some researchers found that knowing subsidy policy has little effect on their decisions. Although China issued policies subsidizing grain seeds and agricultural machines, farmers are reluctant to expand production as a consequence of the low subsidy allocated to each farmer [62]. Farmers prefer leisure time when they are unsatisfied with the manner and amount of the subsidies [63]. Once farmers obtain subsidies, they are willing to invest them in non-agricultural activities that are more profitable [8]. Using panel data from a national survey of 1064 households, Huang et al. [47] found that, although the total subsidy budget of China government is high, the national grain self-sufficiency goals of China are not being achieved.

According to the results, other factors also play a crucial role in farmland transfer. Firstly, educational attainment has a positive influence on farmland transfer [18]. However, the average educational attainment of all farmers examined in this study ranged from junior high school to primary school, which indicates that farmers need to be educated further. Next, age has an inverse relationship with farmland inflow decisions. However, China continues to confront an irreversibly aging society [64,65]. By the end of 2017, there were 24.9 million people aged over 60 in China, accounting for $17.3 \%$ of the total population [49]. It is necessary to promote transformation among older farmers with respect to farmland transfer. Thirdly, the household size and family dependency ratio obstruct small-scale households from becoming moderate-scale households due to multiple generations 
of the family being unable to contribute to the labor force [32]. Ultimately, the non-agricultural labor level has a negative impact on farmland transfer.

A set of measures must be put into effect to improve rural households' perception of moderate-scale subsidy policies. Above all, local governments and agricultural agents should carefully study the content of moderate-scale subsidy policies in advance to make them more effective. Furthermore, they must acknowledge that the radiation effect of negative policy perception could prove detrimental to the policy objectives. It should be guaranteed that policy information will not be distorted in the process of dissemination. In addition, moderate-scale subsidy policies need to be better aligned with the differing situations of rural households in order to play a more effective role in realizing the goal of farmland transfer.

In terms of other determinants, some suggestions are put forward. Considering the positive effect of educational attainment on farmland transfer, investments should be made in improving rural education, and equal educational opportunities should be provided to the rural population. In addition, the formulation of a pension insurance policy and a special social security system is necessary to encourage older farmers to transfer farmland. From the perspective of household size and family dependency ratio, policy-makers should pay attention to the pressures of supporting the non-labor forces in rural households and should provide the necessary support for these households. Finally, actions should be taken to facilitate rural labor transfer to non-agricultural employment. Society should supply not only non-agricultural work opportunities but also occupational training and rural labor.

This paper studied the impact of farmers' perception of moderate-scale subsidy policies on farmland transfer, which fills in a gap in this research field and has some implications for promoting land transfer by improving farmers' awareness of government policies. Beyond China, other countries in the world implement relevant agricultural subsidy policies. In terms of whether the perception of these subsidy policies can affect farmers' decision-making, our study provides some scientific references. However, there is no empirical study on how to improve the awareness rate of farmers, which should be the focus of future research. In addition, owing to China's special national conditions, small-scale farming will not disappear in the coming decades. The coordination of the transition of small-scale farming, off-farm employment, and food security will also be important issues for future studies.

Supplementary Materials: The following are available online at http://www.mdpi.com/2071-1050/11/8/2393/s1, Table S1: The questionnaire about farmers' policy perception; Figure S1: Distribution of moderate-scale household samples.

Author Contributions: Y.Z. conceptualized and designed the research, supervised the whole process, and wrote the original draft; Y.W. performed the data curation and shared the efforts in data analysis; Y.B. contributed to the methodology of the study and provided suggestions to revise the paper. All authors read and approved the final manuscript.

Funding: This research was funded by The Key Deployment Project of the Chinese Academy of Sciences, P.R. China grant number and ZDBS-SSW-DQC and The National Key Research and Development Plan of China, P.R. China grant number 2016YFE0113100.

Acknowledgments: We thank the editor and reviewers for careful review and insightful comments.

Conflicts of Interest: The authors declare no conflicts of interest regarding the publication of this paper.

\section{References}

1. Lowder, S.K.; Skoet, J.; Raney, T. The Number, Size, and Distribution of Farms, Smallholder Farms, and Family Farms Worldwide. World Dev. 2016, 87, 16-29. [CrossRef]

2. Hazell, P.; Poulton, C.; Wiggins, S.; Dorward, A. The future of small farms. Soc. Sci. Electron. Publ. 2011, 32, 93-101.

3. 2016 Global Food Policy Report; International Food Policy Research Institute (IFPRI): Washington DC, USA, 2016.

4. Deininger, K.; Byerlee, D. The rise of large farms in land abundant countries: Do they have a future? World Dev. 2012, 40, 701-714. [CrossRef] 
5. Gong, T.; Battese, G.E.; Villano, R.A. Should smallholder farming in China be discouraged? Panel evidence from Anhui Province. J. Dev. Areas 2019, 53, 33-49. [CrossRef]

6. Yao, G. An empirical study on the moderate scale of food-production-based family farm in Guangxi. Asian Agric. Res. 2016, 8, 22-24.

7. Department of Economic Management and Information, Chinese Ministry of Agriculture. Development of Family Farm in 2016. Rural Manag. 2017, 8, 41-42.

8. Wang, J.Y.; Chen, K.Z.; Gupta, S.D.; Huang, Z.H. Is small still beautiful? A comparative study of rice farm size and productivity in China and India. China Agric. Econ. Rev. 2015, 7, 484-509. [CrossRef]

9. Cui, K.; Shoemaker, S.P. A look at food security in China. npj Sci. Food 2018, 2, 4. [CrossRef]

10. Liu, Y.S.; Wang, J.Y.; Long, H.L. Analysis of arable land loss and its impact on rural sustainability in southern Jiangsu province of China. J. Environ. Manag. 2010, 91, 646-653. [CrossRef] [PubMed]

11. Dong, Y.G. Determinants of Chinese agricultural products restricted by sanitary and phytosanitary measures. Ecol. Econ. 2017, 1, 16-27.

12. Guo, S.; Shen, G.Q.; Chen, Z.M.; Yu, R. Embodied cultivated land use in china 1987-2007. Ecol. Indic. 2014, 47, 198-209. [CrossRef]

13. He, C.; Liu, Z.; Xu, M.; Ma, Q.; Dou, Y. Urban expansion brought stress to food security in china: Evidence from decreased cropland net primary productivity. Sci. Total Environ. 2017, 576, 660-670. [CrossRef]

14. Mukhopadhyay, K.; Thomassin, P.J.; Zhang, J. Food security in China at 2050: A global CGE exercise. J. Econ. Struct. 2018, 7, 1. [CrossRef]

15. Wei, J.; Qing, Y.U. Research on the Moderate Scale Operation of Food. Asian Agric. Res. 2015, 7, 6-8.

16. Singh, R.; Kumar, A.; Singh, K.M.; Kumar, A. Agricultural production performance on small farm holdings: Some empirical evidences from Bihar, India. Soc. Sci. Electron. 2014. [CrossRef]

17. Sudaryanto, T.; Susilowati, S.H.; Sumaryanto, S. Increasing Number of Small Farms in Indonesia: Causes and Consequences; European Association of Agricultural Economists: Canterbury, UK, 2009.

18. Otsuka, K.; Liu, Y.; Yamauchi, F. The future of small farms in Asia. Dev. Policy Rev. 2016, 34, 441-461. [CrossRef]

19. Chinese Ministry of Agriculture; Chinese Ministry of Finance. Guiding Opinions on Adjusting the Three Agricultural Subsidies Policies. Available online: http://nys.mof.gov.cn/zhengfuxinxi/czpjZhengCeFaBu_2_ 2/201505/t20150522_1237664.html (accessed on 14 December 2018).

20. Chinese Ministry of Agriculture. Measures of the People's Republic of China on the Transfer of Rural Land Contracting and Management Rights. Available online: http://zylz.gszwfw.gov.cn/art/2017/12/14/art_201820_ 24261.html (accessed on 14 December 2018).

21. The General Office of the Communist Party of China and the General Office of the State Council. Opinions on Guiding the Orderly Transfer of Rural Land Management Right to Develop Moderate-Scale Agricultural Production. Available online: http://www.gov.cn/xinwen/2014-11/20/content_2781544.htm (accessed on 14 December 2018).

22. Zhang, H. Transfer of Land into the Hand of Wealth: National Rural Production Relations Waiting for Change. Available online: http://www.sohu.com/a/195639238_118622 (accessed on 14 November 2018).

23. Chen, M.Q.; Zhong, T.Y.; Zhou, B.J.; Huang, H.S.; He, W.J. Empirical research on farm households' attitude and behaviour for cultivated land transferring and it's influencing factors in China. Agric. Econ. 2010, 56, 409-420. [CrossRef]

24. Teklu, T.; Lemi, A. Factors affecting entry and intensity in informal rental land markets in Southern Ethiopian highlands. Agric. Econ. 2004, 30, 117-128. [CrossRef]

25. Zhang, C.Y.; Zhu, L.Q. Land quality and production mode: Two important variables influencing on farmland transfer. In Proceedings of the International Conference on Artificial Intelligence, Las Vegas, NV, USA, 18-21 July 2011; pp. 1216-1219.

26. Wang, L.S.; Wang, C.P.; Ma, W. Empirical analysis of peasant household land outflow behavior in major grain producing areas. Adv. Mater. Res. 2014, 962-965, 2229-2233. [CrossRef]

27. Liu, Y.; Liu, H. Analysis on influence factors of farmer desire in farmland circulation. In Proceedings of the 2nd International Conference on Information Science \& Engineering, Hangzhou, China, 4-6 December 2010.

28. Wang, J.Y.; Xin, L.J. Is larger scale better? Evidence from rice farming in Jianghan plain. J. Resour. Ecol. 2018, $9,352-364$. 
29. Du, W.X.; Huang, X.J. Regional difference and influencing factors of farm households' willingness of rural land transmission: A case study of Shanghai, Nanjing, Taizhou and Yangzhou cities in Yangtze-Delta region. Resour. Sci. 2005, 27, 90-94.

30. Zaibet, L.T.; Dunn, E.G. Land tenure, farm size, and rural market participation in developing countries: The case of the Tunisian olive sector. Econ. Dev. Cult. Chang. 1998, 46, 831-848. [CrossRef]

31. Reichenbach, M.; Hagen Jokela, B.; Sagor, E. Family communication and multigenerational learning in an intergenerational land transfer class. J. Ext. 2013, 51, 1-8.

32. Liang, L.; Lin, S.L.; Zhang, Z.X. Effect of the family life cycle on the family farm scale in southern China. Agric. Econ. 2015, 61, 429-440. [CrossRef]

33. Vranken, L.; Swinnen, J. Land rental markets in transition: Theory and evidence from Hungary. World Dev. 2006, 34, 481-500. [CrossRef]

34. Zhang, Q.F.; Ma, Q.G.; Xu, X. Development of land rental markets in rural Zhejiang: Growth of off-farm jobs and institution building. China Q. 2004, 180, 1050-1072. [CrossRef]

35. Xie, H.L.; Lu, H. Impact of land fragmentation and non-agricultural labor supply on circulation of agricultural land management rights. Land Use Policy 2017, 68, 355-364. [CrossRef]

36. Xu, Z.J.; Zhang, S.L.; Hou, H.P.; Luo, X. Model and model implement of farmland circulation in China. Am. J. Vet. Res. 2010, 64, 21-23.

37. Ji, X.; Qian, Z.; Zhang, L.; Zhang, T. Rural labor migration and households' land rental behavior: Evidence from China. China World Econ. 2018, 26, 66-85. [CrossRef]

38. Deininger, K.; Zegarra, E.; Lavadenz, I. Determinants and impacts of rural land market activity: Evidence from Nicaragua. World Dev. 2003, 31, 1385-1404. [CrossRef]

39. Yuan, S.F.; Li, F.; Wang, X.C. Study on households' willingness in farmland transfer: A case of Tengtou village, Fenghua in Zhejiang province, China. Appl. Mech. Mater. 2014, 675-677, 1238-1241. [CrossRef]

40. Noev, N. Contracts and rental behavior in the Bulgarian land market. East. Eur. Econ. 2008, 46, 43-74. [CrossRef]

41. Awasthi, M.K. Dynamics and resource use efficiency of agricultural land sales and rental market in India. Land Use Policy 2009, 26, 736-743. [CrossRef]

42. Chen, D.; Ren, Y.; Dai, Y.K. How rural land transfer affect labor migration decision in China? Chin. Rural Econ. 2017, 7, 56-71. (In Chinese)

43. Geiger, F.; Bengtsson, J.; Berendse, F.; Weisser, W.W.; Emmerson, M.; Morales, M.B. Persistent negative effects of pesticides on biodiversity and biological control potential on European farmland. Basic Appl. Ecol. 2010, 11, 97-105. [CrossRef]

44. Niyogi, D.; Kishtawal, C.; Tripathi, S.; Govindaraju, R.S. Observational evidence that agricultural intensification and land use change may be reducing the Indian summer monsoon rainfall. Water Resour. Res. 2010, 46, 91-103. [CrossRef]

45. Ministry of Agriculture of Shandong Province. Raising the Subsidy Standard for Large Grain Growers and Family Farms in Shandong Province. Available online: http://czt.shandong.gov.cn/art/2015/10/26/art_21859_ 4156781.html (accessed on 14 November 2018).

46. Yi, F.J.; Sun, D.Q.; Zhou, Y.H. Grain subsidy, liquidity constraints and food security-Impact of the grain subsidy program on the grain-sown areas in China. Food Policy 2015, 50, 114-124. [CrossRef]

47. Meng, L. Can grain subsidies impede rural-urban migration in hinterland China? Evidence from field surveys. China Econ. Rev. 2012, 23, 729-741. [CrossRef]

48. Raut, N.; Sitaula, B.K. Assessment of fertilizer policy, farmers' perceptions and implications for future agricultural development in Nepal. Sustain. Agric. Res. 2012, 1, 188-200. [CrossRef]

49. China Statistics Bureau. Shandong Statistical Yearbook; China Statistics Press: Beijing, China, 2018.

50. Huang, J.; Xu, D.L.; Bai, Q.J.; Zhou, X.B. Analysis on development potential of agricultural resources of farming system in Shandong province. Agric. Sci. Technol. (Engl. Ed.) 2012, 13, 401-404.

51. Xinhua News Agency; Farmland Transfer Area in Shandong Province Exceeds 30 Million mu. Available online: http://www.gov.cn/shuju/2017-12/01/content_5243768.htm (accessed on 14 December 2018).

52. Zeng, H.; Chen, M.Q.; Zhou, B.J. Empirical study on the will of farmland transfer among different farmer groups-A sampling survey on 42 counties and cities, 64 towns and 74 villages in Jiangxi province. Asian Agric. Res. 2011, 3, 58-62. 
53. Xu, H.Z.; Guo, Y.Y.; Wu, G.C.; Jin, J. Analysis on influencing factors of migrant workers willingness of land transfer under the perspective of intergenerational difference: An empirical study based on questionnaires of 613 migrant workers in Tianjin city. Resour. Sci. 2012, 34, 1864-1870. (In Chinese)

54. Yang, H.; Chen, G.P.; Economics, S.O. A study of the factors that affect farmers' willingness to transfer land in the central regions based on a survey of 180 farmers in Suzhou city. Asian Agric. Res. 2016, 8, 98-100.

55. Guindon, G.E.; Lavis, J.N.; Boupha, B.; Shi, G.; Sidibe, M.; Turdaliyeva, B. Bridging the gaps among research policy and practice in ten low- and middle-income countries: Development and testing of a questionnaire for health-care providers. Health Res. Policy Syst. 2010, 8, 3. [CrossRef]

56. Gyal, T. Research and analysis on the current situation and re-employment of farmers who lost lands in the saburb communities in Gansu and Qinghai Tibetan inhabited areas. Tibet. Stud. 2007, 57, 187.

57. Latruffe, L.; Piet, L.; Dupraz, P.; Le Mouël, C.H. Influence of Agricultural Support on Sale Prices of French Farmland: A Comparison of Different Subsidies, Accounting for the Role of Environmental and Land Regulations; Factor Market Working Papers; Centre for European Policy Studies: Brussels, Belgium, 2013.

58. Zhang, L.; Feng, S.Y.; Qu, F.T. Regional differences of farmland transfer and its influencing factors: A case study of Jiangsu province. China Land Sci. 2014, 28, 73-80. (In Chinese)

59. Pei, S.; Xie, G.D.; Zhang, Y.S. Study on farmers' willingness and government role in farmland circulation-A case study of the urban and natural rural balancing test site in Jiangbei district of Chongqing municipality. China Popul. Resour. Environ. 2011, 2, 344-360. (In Chinese)

60. Cheng, Y.S.; Chung, K.S. Designing property rights over land in rural China. Econ. J. 2018, 128, $2676-2710$. [CrossRef]

61. Gronewold, K.L.; Burnett, A.; Meister, M. Farmers' cynicism toward nature and distrust of the government: Where does that leave conservation buffer programs? Appl. Environ. Educ. Commun. 2012, 11, 18-24. [CrossRef]

62. Gale, F.; Lohmar, B.T.; Tuan, F.C. China's New Farm Subsidies. In Electronic Outlook Report from the Economic Research Service; WRS0501; United States Department of Agriculture: Washington DC, USA, 2005; Volume 16.

63. Xiao, Q. A statistical evaluation and analysis of the output effect of grain investment subsidy policy. J. Kunming Univ. Sci. Technol. 2012, 12, 65-68. (In Chinese)

64. Flaherty, J.H.; Liu, M.L.; Ding, L.; Dong, B.; Ding, Q.; Li, X. China: The aging giant. J. Am. Geriatr. Soc. 2007, 55, 1295-1300. [CrossRef] [PubMed]

65. Banister, J.; Bloom, D.E.; Rosenberg, L. Population Aging and Economic Growth in China. Program Glob. Demogr. Aging Work. Pap. 2010, 23, 61-89. 